\title{
UPAYA MENJAGA KESEHATAN IBU DAN ANAK DI MASA PANDEMI COVID 19 DI KELURAHAN MALABERO KOTA BENGKULU
}

\author{
Dwi Putri Sulistiya Ningsih ${ }^{1 *}$; Ida Rahmawati ${ }^{2}$; Rafidaini Sazarni ${ }^{3}$; \\ Mika Oktarina ${ }^{4}$; Violita Siska Mutiara ${ }^{5}$ \\ 1,2,3,4,5STIKES Tri Mandiri Sakti Bengkulu \\ *Korespondensi: dwiputri238@gmail.com
}

\begin{abstract}
ABSTRAK
Latar Belakang: Pandemi Covid-19 memberikan dampak secara global pada perekonomian dan juga kesehatan, salah satunya masalah kesehatan ibu dan anak. Kehidupan masyarakat di Kelurahan Malabero Kota Bengkulu yang mayoritas bekerja sebagai nelayan dengan tingkat perekonomian menengah kebawah secara tidak langsung menjadi kelompok yang terdampak akibat pandemic Covid-19. Oleh karena itu, perlu adanya upaya dalam meminimalisir dampak dari Pandemi Covid-19 ini terhadap kesehatan ibu dan juga nutrisi anak. Tujuan dari kegiatan ini adalah memberikan pendampingan kepada masyarakat di Kelurahan Malabero untuk dapat meminimalisir dampak kesehatan akibat Covid-19 terhadap Ibu dan Anak. Metode: Metode yang digunakan yaitu pendampingan dengan penyuluhan menggunakan leaflet dan brosur. Sasarannya adalah Ibu-Ibu yang tinggal di Kelurahan Malabero Kota Bengkulu. Hasil: Peran aktif ibu-ibu pada saat pelaksanaan kegiatan, tampak dari keaktifan ibu-ibu saat diskusi dan sesi tanya jawab. Simpulan: Harapannya dengan dilaksanakan kegiatan ini agar masalah kesehatan yang masih terjadi pada ibu dan anak-anak dapat diminimalisir seperti kasus kematian ibu, diare pada anak, stunting, dan lainnya.
\end{abstract}

Kata kunci: Kesehatan Ibu dan Anak, Covid 19, Bengkulu

\section{ABSTRACT}

The Covid-19 pandemic has a global impact on the economy and health, one of which is the health problem of mothers and children. The lives of people in Malabero Urban Village, Bengkulu City, who mostly work as fishermen with middle to lower economic levels, are indirectly the groups affected by the Covid19 pandemic. Therefore, there is a need for efforts to minimize the impact of the Covid-19 Pandemic on maternal health and children's nutrition. The purpose of this activity is to provide assistance to the community in Malabero Village to be able to minimize the health impact of Covid-19 on mothers and children. The method used is assistance with counseling using leaflets and brochures. The 
targets are mothers who live in Malabero Village, Bengkulu City. The active role of the mothers during the implementation of the activity was evident from the active participation of the mothers during the discussion and question and answer session. The hope is that by carrying out this activity, health problems that still occur in mothers and children can be minimized, such as cases of maternal death, diarrhea in children, stunting, and others.

Keywords: Maternal and child health, Covid 19, Bengkulu

\section{PENDAHULUAN}

Corona virus adalah keluarga besar virus yang menyebabkan penyakit mulai dari gejala ringan sampai berat. Ada setidaknya dua jenis coronavirus yang diketahui menyebabkan penyakit yang dapat menimbulkan gejala berat seperti Middle East Respiratory Syndrome (MERS) dan Severe Acute Respiratory Syndrome (SARS). Coronavirus Disease 2019 (COVID-19) adalah penyakit jenis baru yang belum pernah diidentifikasi sebelumnya pada manusia. Virus penyebab COVID-19 ini dinamakan Sars-CoV-2. Virus corona adalah zoonosis (ditularkan antara hewan dan manusia). Penelitian menyebutkan bahwa SARS ditransmisikan dari kucing luwak (civet cats) ke manusia dan MERS dari unta ke manusia. Adapun, hewan yang menjadi sumber penularan COVID-19 ini sampai saat ini masih belum diketahui ((Kemenkes, 2020)

Covid-19 diidentifikasi di Wuhan, Cina pada bulan Desember 2019. Covid19 disebabkan oleh virus sindrom pernafasan akut berat coronavirus 2 (SARSCoV-2), virus baru pada manusia yang menyebabkan penyakit pernapasan yang dapat menyebar dari orang ke orang. Pada awal wabah, banyak pasien dilaporkan memiliki keterkaitan dengan makanan laut besar dan pasar hewan hidup, namun kasus selanjutnya tidak ada kaitannya dengan pasar kemudian dikonfirmasi penularan penyakit dari orang ke orang. Selain itu kasus ekspor penyakit telah terjadi (Center for Disease Control and Prevention (CDC), 2020).

Covid-19 ditularkan dari orang ke orang melalui droplets (percikan air liur). Droplet ini keluar saat seseorang yang menderita Covid-19 bersin, batuk, atau berbicara. Droplet dari orang yang terinfeksi dapat mendarat di mulut atau hidung oranglain yang berada di dekatnya atau mungkin terhirup ke dalam paru-paru. 
Jarak fisik setidaknya 1 meter (3 kaki) antara orang-orang yang disarankan oleh World Health Organization (WHO) untuk menghindari penularan, meskipun beberapa negara anggota WHO telah merekomendasikan untuk menjaga jarak yang lebih jauh. Tetesan droplet dapat mendarat di tangan, atau permukaan benda disekitar ketika seseorang batuk atau berbicara dan orang lain kemudian dapat terinfeksi Covid-19 dari menyentuh tangan, benda atau permukaan dengan tetesan droplet dan kemudian menyentuh mata, hidung, atau mulut mereka. Data terbaru menunjukkan bahwa kemungkinan terjadi penularan Covid-19 melalui tetesan dari mereka yang memiliki gejala ringan atau mereka yang tidak merasa sakit (Center for Disease Control and Prevention (CDC), 2020).

Data saat ini tidak mendukung penularan SARS-CoV-2 aerosol jarak jauh, seperti pada campak atau tuberculosis. Menghirup aerosol jarak pendek adalah kemungkinan untuk Covid-19, seperti pada banyak pathogen pernapasan. Namun hal ini tidak dapat dengan mudah dibedakan dari transmisi droplet berdasarkan pola epidemiologi. Penularan jarak pendek dimungkinkan terutama di bangsal medis yang padat dan ruangan yang tidak memiliki ventilasi yang memadai. Prosedutr tertentu di fasilitas kesehatan dapat mengahsilkan aerosol halus dan harus dihindari jika memungkinkan (Center for Disease Control and Prevention (CDC), 2020).

Penyakit Covid-19 terus merusak kesehatan dan matrik ekonomi secara global, termasuk kesehatan ibu dan nutrisi pada anak. Tingkat kekurangan gizi juga cenderung meningkat akibat pandemi Covid-19 termasuk juga dampaknya pada angka kemiskinan dan akses ke makanan bergizi (Akseer et al., 2020). Secara global, pandemi Covid-19 telah menjadi penyebab utama peningkatan pengangguran dan diharapkan menyebabkan peningkatan kemiskinan dan ketidakamanan pangan serta gizi yang berujung dengan hasil kesehatan yang buruk. Keluarga dimana anak-anak kecil, remaja, wanita hamil dan menyusui perlu dilindungi dari pandemi. Karena makanan, gizi, kesehatan, dan hasil social ekonomi saling terkait erat, penting bagi kita untuk melakukan edukasi dan promosi kepada masyarakat (Pérez-Escamilla et al., 2020). 
Pandemi Covid-19 secara umum menurunkan jumlah kunjungan ke layan gizi dan kesehatan Ibu dan Anak (KIA), terutama layanan imunisasi dasar dan penimbangan anak dibawah lima tahun. Di Indonesia, pandmei Covid-19 berpotensi menghambat akses ibu dan anak terhadap layanan kesehatan yang optimal. Penurunan jumlah kunjungan ke layanan gizi dan KIA juga berpotensi memunculkan masalah gizi dan kesehatan baru seperti bertambahnya angka gizi buruk, stunting dan juga penyakit infeksi lainnya. Selain itu studi lain menemukan indikasi keengganan masyarakat untuk mengimunisasi, menimbang anak dan memeriksakan kehamilan mereka selama masa pandemic di fasilitas kesehatan karenatakut tertular virus Covid-19 (Saputri., dkk, 2020).

Hasil survey Wahana Visi Indonesia periode 12-18 Mei 2020 terhadap 900 rumah tangga, 943 anak, dan 15 informan kunci menyatakan mata pencaharian 9 dari 10 responden rumah tangga terdampak dan 7 dari 10 terdampak parah Covid19. Akibatnya, kemampuan rumah tangga menyediakan makan utama sesuai standar frekuensi untuk anak, ibu hamil dan menyusui terburuk pada rumah tangga dengan bayi berusia 6-9 bulan, hanya 39\% yang menyatakan mampu. Hanya 20,4\% rumah tangga mengaku memiliki persediaan makan lebih dari sebulan. Sebaliknya, mayoritas justru dapat menyediakan makanan maksimal seminggu. Kondisi ini bias meningkatkan risiko malnutrisi akut dan kronis pada ana. (Jayani, 2020).

Masalah yang telah teridentifikasi pada Kelurahan Malabero Kota Bengkulu, yaitu mayoritas masyarakat di Kelurahan Malabero adalah nelayan dengan tingkat perekonomian menengah kebawah. Ditengah pandemic Covid-19 yang berdampak hampir diseluruh sector termasuk kesehatan dan perekonomian berdampak langsung pada kesehatan ibu dan anak diwilayah tersebut. Dari masalah tersebut perlu adanya upaya dalam meminimalisir dampak dari Pandemi Covid-19 ini terhadap kesehatan ibu dan juga nutrisi anak. Tujuan dari kegiatan ini adalah memberikan pendampingan kepada masyarakat di Kelurahan Malabero 
untuk dapat meminimalisir dampak kesehatan akibat Covid-19 terhadap Ibu dan Anak.

\section{METODE}

Sasaran dari kegiatan pengabdian masyarakat ini adalah Ibu-Ibu yang tinggal di Kelurahan Malabero Kota Bengkulu. Metode yang digunakan dalam kegiatan pengabdian ini adalah penyuluhan dan edukasi menggunakan media leaflet dam brosur. Leaflet dan brosur berisi materi tentang Covid-19 mulai dari pengertiannya, gejala, cara pencegahannya dan upaya dalam menjaga kesehatan Ibu dan Anak selama masa Pandemi. Kegiatan pengabdian masyarakat ini dilaksanakan pada hari Jum'at tanggal 23 Oktober 2020.

\section{HASIL, PEMBAHASAN, DAN DAMPAK}

Upaya pendampingan, edukasi dan promosi kesehatan kepada ibu-ibu di Kelurahan Malabero Kota Bengkulu berjalan dengan baik dan lancar. Tim tetap mematuhi protocol kesehatan pada saat pelaksanaan kegiatan. Pada kegiatan pengabdian masyarakat ini, tim menggunakan leaflet dan brosur sebagai alat bantu ketika melakukan pendampingan. Kegiatan dilaksanakan pada hari Jum'at tanggal 23 Oktober 2020, setelah sebelumnya tim telah berkoordinasi dengan Pak lurah dan mendapatkan izin pelaksanaan kegiatan.

Pada kegiatan ini masyarakat yang terlibat sebanyak \pm 50 orang Ibu-ibu perwakilan dari masing-masing RT. Mengingat kegiatan dilakukan pada saat pandemi Covid-19, maka peserta yang terlibat harus dibatasi agar tidak menimbulkan keramaian dan juga melanggar protocol kesehatan yang ditetapkan. 
Tabel 1. Hasil Kegiatan Pengabdian Masyarakat di Kelurahan Malabero

\begin{tabular}{ccccc}
\hline No. & $\begin{array}{c}\text { Jumlah Peserta } \\
\text { Undangan }\end{array}$ & RT & $\begin{array}{c}\text { Peserta } \\
\text { yang hadir }\end{array}$ & Frekuensi \\
\hline 1. & 6 orang & 1 & 6 orang & $100 \%$ \\
2. & 6 orang & 2 & 6 orang & $100 \%$ \\
3. & 6 orang & 3 & 6 orang & $100 \%$ \\
4. & 6 orang & 4 & 5 orang & $83,3 \%$ \\
5. & 6 orang & 5 & 6 orang & $100 \%$ \\
6. & 6 orang & 6 & 5 orang & $83,3 \%$ \\
7. & 6 orang & 7 & 5 orang & $83,3 \%$ \\
8. & 6 orang & 8 & 5 orang & $83,3 \%$ \\
9. & 6 orang & 9 & 6 orang & $100 \%$ \\
\hline TOTAL & 54 orang & - & 50 orang \\
\hline
\end{tabular}

Masyarakat khususnya ibu-ibu memberikan respon yang postif pada kegiatan pengabdian masyarakat ini. Mereka merasa bersyukur ditengah-tengah keadaan sedang pandemic seperti ini masih ada yang tetap perhatian dengan mereka. Respon positif yang diberikan tersebut adalah berperan aktif mengikuti rangkaian kegiatan yang tampak dari beberapa foto yang dilampirkan.

Menurut Wiryasaputra, 2006, sebagian praktisi menganggap pendampingan sebagai konsultasi. Orientasi ini mengarahkan pendampingan sebagai hubungan antara seorang ahli dan bukan ahli. Orang yang didampingi dianggap tidak mempunyai pengetahuan dan kemampuan apa-apa. Sedangkan pendamping dipandang sebagai seorang ahli yang mengetahui segala sesuatu, khususnya seluk beluk persoalan yang dialami oleh orang didampingi. Pendampig dianggap dapat memecahkan semua masalah yag ada. Tujuan pendampingan adalah pemberdayaan atau penguatan (empowerment). Pemberdayaan bearti mengembangkan kekuatan atau kemampuan (daya), potensi, sumber daya rakyat agar mampu membela dirinya sendiri. Hal yang paling inti dalam pemberdayaan adalah peningkatan kesadaran (consciousness) (Wiryasaputra, 2006). 


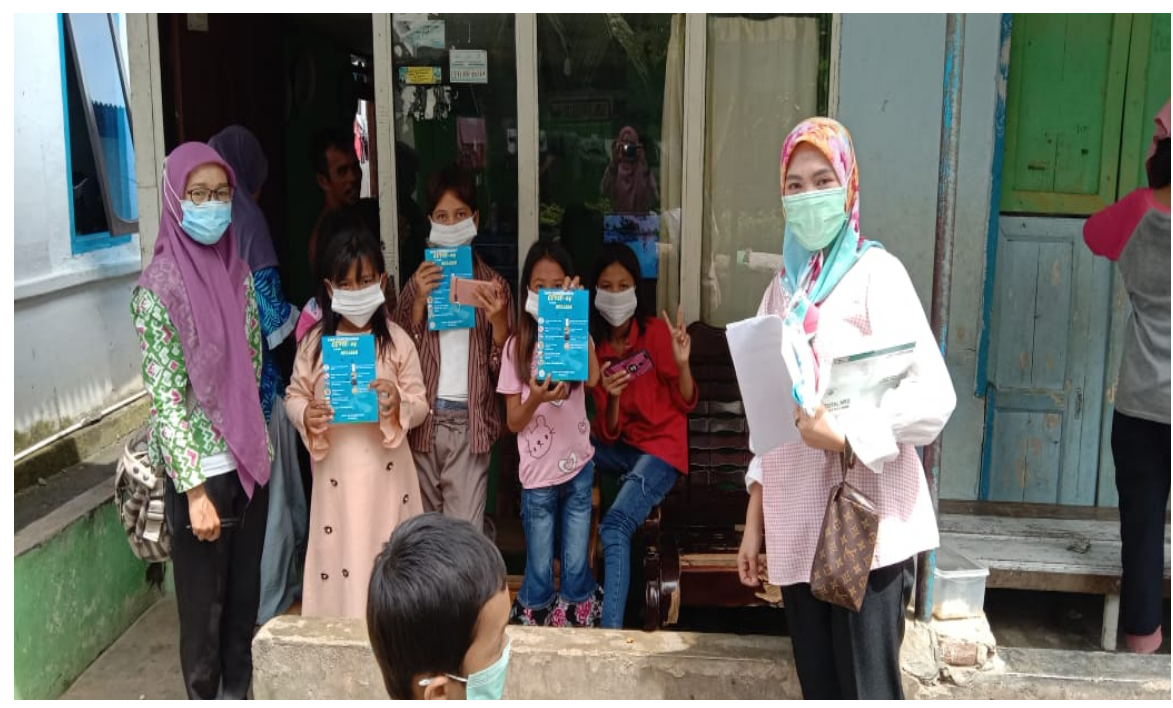

Gambar 1. Tim Pengabdian Kesehatan Bersama Anak-Anak di Kelurahan Malabero

Salah satu model pendampingan adalah penyuluhan. Pendekatan pemberdayaan masyarakat lokal yang mandiri sebagai suatu system yang mengorganisir diri mereka sendiri. Menurut Maulana, (2009), manfaat penyuluhan kesehatan adalah a). Penyuluhan kesehatan dapat mengajarkan kepada sasaran mengenai cara-cara hidup yang sehat agar dapat menjadi kebiasaan hidup sehari-hari. b). Penyuluhan kesehatan dapat membantu individu maupun kelompok untuk mengatasi sebuah masalah kesehatannya agar dapat mencapai derajat kesehatan yang baik. c). Penyuluhan kesehatan dapat meningkatkan pengetahuan individu atau kelompok sehingga harapannya telah dilakukan penyuluhan kesehatan maka dapat merubah perilakunya menjadi perilaku hidup yang sehat. 


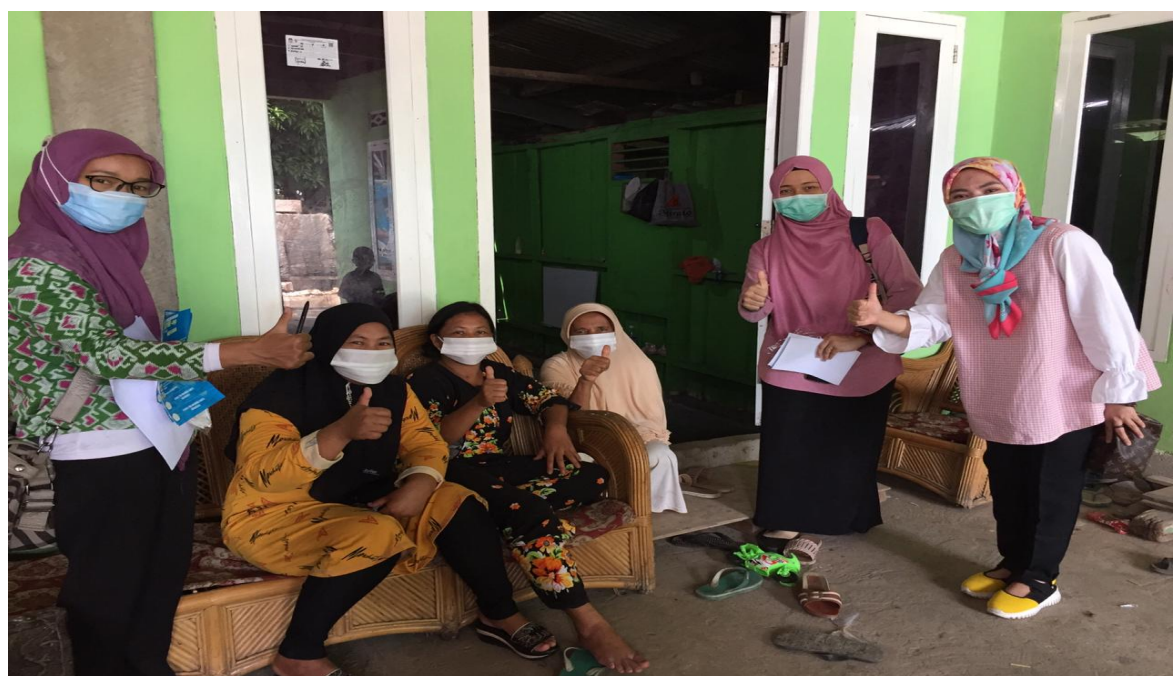

Gambar 2. Tim Bersama Ibu-Ibu di Kelurahan Malabero

Dalam kegiatan pendampingan ini tim menggunakan media cetak sebagai alat bantu dalam memberikan penyuluhan, leaflet dan brosur menjadi pilihan tim dalam melakukan intervensi. Media cetak mengutamakan pesan-pesan visual, biasanya terdiri dari gambaran sejumlah kata, gambar atau foto dalam tata warna. Beberapa kelebihan media cetak antara lain tahan lama, mencakup banyak orang, biaya rendah, dapat dibawa kemana-mana, tidak perlu listrik, mempermudah pemahaman dan dapat meningkatkan gairah belajar. Media cetak memeiliki kelemahan yaitu tidak dapat menstimulir efek gerak dan efek suara dan mudah terlipat (Susilowati, 2016). 


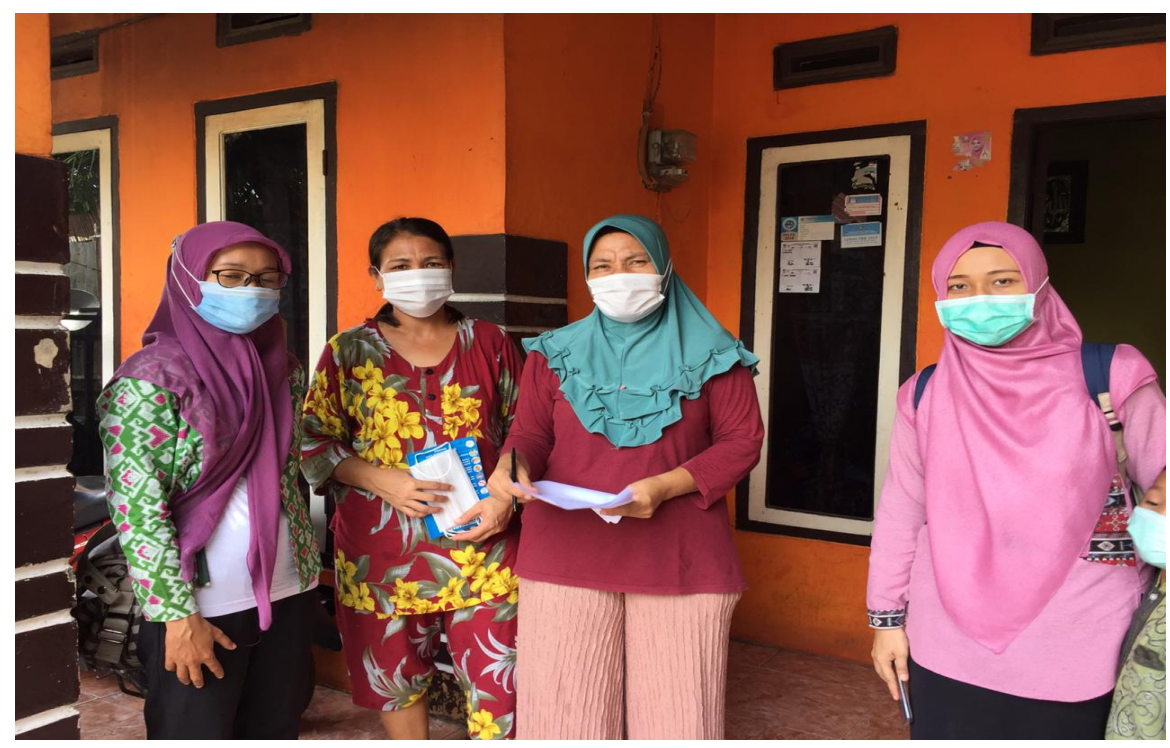

Gambar 3. Tim Bersama Salah Satu Keluarga Di Kelurahan Malabero

Kegiatan pendampingan kepada ibu-ibu di Kelurahan Malabero dalam upaya menjaga kesehatan ibu dan anak dimasa pandemi Covid-19 berjalan dengan baik. Peran aktif ibu-ibu pada saat pelaksanaan kegiatan, tampak dari keaktifan ibu-ibu saat diskusi dan sesi tanya jawab. Harapannya dengan dilaksanakan kegiatan ini agar masalah kesehatan yang masih terjadi pada ibu dan anak-anak dapat diminimalisir seperti kasus kematian ibu, diare pada anak, stunting, dan lainnya. Meskipun saat in tengah Pandemi Covid-19, ibu-ibu jangan khawatir untuk tetap membawa anaknya ke posyandu dan juga imunisasi wajib kepada anak-anak mereka dengan tetap mematuhi protocol kesehatan yang ada.

\section{KESIMPULAN}

Kegiatan pengabdian masyarakat di Kelurahan Malabero Kota Bengkulu telah dilaksanakan dan berjalan dengan baik dan lancar. Kegiatan dilakukan dengan mengunakan leaflet dan brosur sebagai metode pendampingan edukasi dan promosi kepada para ibu-ibu yang tinggal di Keluarahan Malabero. Pendampingan ini dilakukan dengan memberikan materi tentang Covid-19 mulai dari pengertiannya, gejala, cara pencegahannya dan upaya dalam menjaga kesehatan Ibu dan Anak selama masa Pandemi. Dengan adanya kegiatan 
pendampingan edukasi dan juga promosi kepada ibu-ibu dan anak-anak di Kelurahan Malabero diharapkan dapat meminimalisir dampak buruk kesehatan pada ibu dan anak pada masa pandemic Covid-19.

\section{UCAPAN TERIMA KASIH}

Tim pelaksana kegiatan pengabdian masyarakat mengucapkan terima kasih kepada Lurah Kelurahan Malabero Kota Bengkulu, dan ibu-ibu yang tinggal di Kelurahan Malabero yang telah membantu dan juga mendukung kegiatan pengabdian masyarakat ini sehingga dapat terlaksana dengan baik. 


\section{DAFTAR PUSTAKA}

Akseer, N., Kandru, G., Keats, E. C., \& Bhutta, Z. A. (2020). COVID-19 pandemic and mitigation strategies: Implications for maternal and child health and nutrition. American Journal of Clinical Nutrition, 112(2), 251256. https://doi.org/10.1093/ajen/nqaa171

Centers for Disease Control and Prevention CDC). 2020. Coronavirus (Covid-19) 2020. https://www.cdc.gov/

Jayani, D, H. 2020. Gizi Anak Indonesia berpotensi Memburuk Saat Pandemi Covid 19. Jurnalisme Data https://katadata.co.id/0/analisisdata/5f6c0f86a5911/gizi-anak-indonesiaberpotensi-memburuk-saat-pandemi-covid-19.

Kemenkes. (2020). Pedoman kesiapan menghadapi COVID-19. Pedoman Kesiapan Menghadapi COVID-19, 0-115.

Maulana, Heri, d.j. 2009. Promosi Kesehatan. Jakarta: Penerbit Buku Kedokteran EGC.

Pérez-Escamilla, R., Cunningham, K., \& Moran, V. H. (2020). COVID-19 and maternal and child food and nutrition insecurity: a complex syndemic. Maternal and Child Nutrition, 16(3), 8-11. https://doi.org/10.1111/mcn.13036

Saputri, Nurmala S., Anbarani Maudita D., Toyamah N., Yumna A. 2020. Dampak Pandmei Covid-19 Pada Layanan Gizi dan Kesehatan Ibu dan Anak (KIA): Studi Kasus Di Lima Wilayah Di Indonesia. Catatan Penelitian SMERU N0.5/2020. SMERU Research Institute.

Susilowati, D. 2016. Modul Bahan Ajar Cetak Keperawatan. Promosi Kesehatan. Pusdik SDM Kesehatan, Badan Pengembangan dan Pemberdayaan Sumber daya Manusia Kesehatan.

Wiryasaputra, Totok.S. 2006. Ready To Care: Pendmapingan dan Konseling Psikoterapi.Yogyakarta: Galang Press. 